\title{
連載ミニレビュー
}

\section{作物の形態研究法：マクロからミクロまで マメ科作物における根粒形成過程の観察法}

\author{
大門弘幸・朝倉草平・坂本えみ子 \\ (大阪府立大学大学院生命環境科学研究科)
}

\begin{abstract}
マメ科作物への根粒菌の侵入経路は大きく二つに分けられ，根毛内に形成した感染系を通して菌体が根粒原基細胞 に侵入する経路と，感染糸を経ずに細胞間隙から細胞壁を貫入して侵入する経路がある。これらは電子顕微鏡による 細胞微細構造の観察と発色標識遺伝子を導入した根粒菌の利用によっていくつかの作物でより明確になってきた。 各 マメ科作物の根に抢ける根粒菌の挙動や根粒形成の様相を様々な生育条件に扔いて探るには，供試作物の種子の大き さや初期生育の遅速などによって観察するための実験系を工夫する必要がある。ここでは，根粒菌の感染から根粒構 造の形成過程を観察する方法について概略を述べる。
\end{abstract}

\section{1. 根粒形成の観察}

根箱やグロースポーチで作物を栽培すれば根系の生長を 経時的に捉えることができるが，マメ科作物の根粒形成の 様子もこれらの方法で観察できる。ここでは，生育初期の 根系構造の変化と根粒形成との関係が把握しやすいグロー スポーチ法とスライドグラス法について概説する.

グロースポーチ (http://www.mega-international.com/) 法は, 培養液を保持する紙が入ったポリビニール製の透明な袋 $(18 \mathrm{~cm} \times 16 \mathrm{~cm})$ に種子を置床し, 紙の表面を根が生長す る様子や根粒の形成位置を観察する方法である。オートク レーブしたポーチと紙を用い, 表面殺菌した種子を置床し, 滅菌した培養液を添加すれば雑菌の繁殖は抑制できる。 ラックに並べたポーチ上部を子葉が展開するまでラップで 被覆してポーチからの蒸発量を少なくすれば実生の生育が 均一になる，2〜3 日に 1 回，ポーチごと計量して生育に ともなって減少した水分を補給する。排水して根の生育が 見える面（ポーチ面）をスキャナで取り込むか，ラップを 広げたスキャナ上に水を注ぎ, 取り出した根を注意深く広 げてスキャンすれば，根粒着生部位を画像として保存でき る. ポーチ面を解剖顕微鏡で直接観察すれば根粒着生の様 子がよくわかる（第 1 図 $\mathrm{A}$ )。なお，培養液の $\mathrm{pH}$ と $\mathrm{EC} の$ 変化は, 経時的に測定し, 培養液交換時期の目安とする.

スライドグラス法は，隙間を設けてカバーグラスを接着 したスライドグラスに種子を置床し，培養液を分注した染 色バットなどに立てて培養し, 根毛の発達やカーリングを 観察する方法である（Niwa ら 2001; http://miya.bio.sci.osakau.ac.jp/manuals/index.html)，スライドグラスにシリコンコー ティング剤を 4 点滴下して，カバーグラス（例えば $24 \times$ $40 \mathrm{~mm}$ ，厚さ 0.12-0.17 mm）を押しあてて，グラスの隙 間を 1 2 mm 程度として接着すればよい（第 1 図 B)。1
晚静置して完全に接着し乾燥させる. 使用器具類を予め滅 菌し, 観察時にはスライドグラスユニットをクリーンベン チ内で取り出し滅菌シャーレに入れて顕微鏡観察すれば, 無菌的に生育させたものを経時的に観察できる。

いずれの方法も目的に合わせて施用する培養液を選択す るが, 著者らは, Broughton \& Dilworth の無窒素培地 （Dilworth 1980）を用い, 必要に応じて硝酸カリウムを N として 10〜30 mM 添加している。 なお，上記のサイズで 作製したスライドグラスユニットは種子の大きい作物には 利用しにくい.

根粒菌は予め液体振とう培養して増殖させ, 吸光度 $\left(\mathrm{OD}_{620 \mathrm{~nm}}\right)$ を測定後に遠心分離して集菌し, 滅菌水で目的 とする菌密度に希釈して接種する。播種前に種子を希釈液 に浸漬するかポーチやバット内に $1 \mathrm{~mL}$ 程度を施用すれば 根粒が形成される。
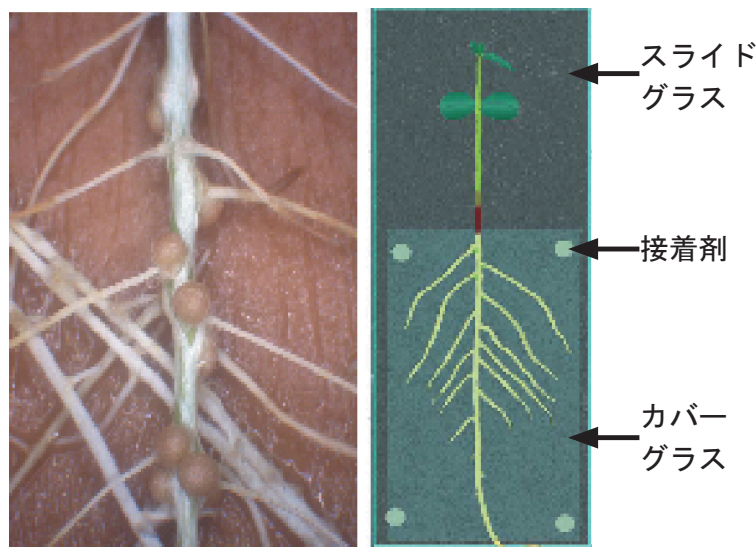

第 1 図 A: グロースポーチで生育させたラッカセイに形成さ れた根粒（接種 14 日目), B: スライドグラス法で用いる グラスユニットの模式図. 


\section{2. 発色標識遺伝子の根粒菌への導入}

オワンクラゲ由来の緑色蛍光タンパク遺伝子 (GFP) や大 腸菌由来の $\beta$ - グルクロニダーゼ遺伝子 (GUS) あるいは $\beta$ - ガラクトシダーゼ遺伝子 (LacZ) などの発色標識遺伝 子を根粒菌に導入することによって, 菌の根への付着, 組 織内への侵入経路, 接種菌による根粒形成の割合などを視 覚的にとらえることができる。著者は，K. J. Wilson 博士か ら, 大腸菌の S17- $\lambda$ pir 系統（プロリン要求性株）にクロー ニングされた pCAM121(mTn5SSgusA21) というべクターに のっている gus $A$ 遺伝子を分譲して頂いた。このべクター は自己伝達しないプラスミドであり, 接合伝達に必要な遺 伝子が供給された時にのみ可動化されて他の細菌に伝達さ れる。このプラスミドは大腸菌では複製されるが根粒菌内 では保持されない，根粒菌内にこのべクターが入るとべク ターの消滅と同時にトランスポゾンが染色体内に組み込ま れる仕組みになっている (Wilson, 1995).

著者らはラッカセイ菌 (Bradyrhizobium sp. U9709-A 株) への導入を試みた (Uheda ら 2001). 接合伝達に先立ち, このプラスミド上にある抗生物質抵抗性遺伝子（スペクチ ノマイシン $(\mathrm{Sp})$ とストレプトマイシン $(\mathrm{Sm}))$ を選抜に 利用できるか否かを確認した。供試ラッカセイ菌は, Sp (50 $\left.\mathrm{mg} \mathrm{L}^{-1}\right)$ および $\mathrm{Sm}\left(250 \mathrm{mg} \mathrm{L}^{-1}\right)$ に感受性であった。つ ぎに, 接合伝達の際に用いる最小培地（BD-minimal）の炭 素源を決めるために, グルコース, マンノース, グリセロー ルについて, それぞれ $2 \mathrm{~g} \mathrm{~L}^{-1}$ の濃度で培地に添加して増 殖程度を調査したところ，マンノースで生育が優れた。接 合伝達は, Wilson (1995), 皆川ら (1997), Yuhashi ら (1997), Akao ら（1999）にしたがって行った。すすなわち，Sp と Sm を添加したプロリンを含まない BD-minimal 培地（この条

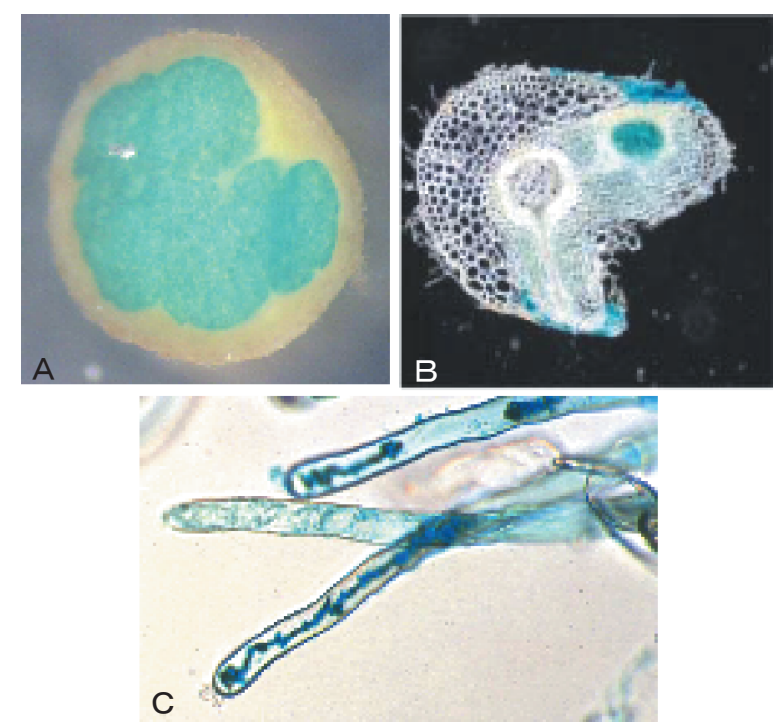

第 2 図 gusA 遺伝子が発現して青色発色した, A: ラッカセイ の根粒, B: セスバニア側根の根粒原基, C: クロタラリア 根毛内の感染糸.
件では形質転換された根粒菌だけが生存できる）に接合後 の菌体希釈液を画線培養してコロニーを選抜した.gus A 遺伝子導入の有無は, 5-Bromo-4-chloro-3-indolyl- $\beta$-Dglucuronide (X-GlcA) ナトリウム塩を $100 \mu \mathrm{g} \mathrm{mL}^{-1}$ 添加した 同様の寒天培地を $1 \mathrm{~mL}$ 分注したマイクロチューブに, 得 られたコロニーを釣菌して穿孔接種し，その際の発色（イ ンジゴ青) で確認した。 得られた菌株は, 細菌類を保存す る際の定法にしたがって冷凍保存した。

これらの菌株を接種実験に利用する場合には, 導入菌株 と野生菌株の増殖力に差異があるか否かを液体培地におけ る $\mathrm{OD}_{620}$ 值の経時的変化から検討しておく必要がある.さ らに, 根粒着生能の差異の有無については, 両菌株を単独 ならびに混合して接種して, 形成された根粒が青色発色す る割合を調べて確認しておくことが必要である。根粒の GUS アッセイは，アッセイ用緩衝液で充分洗浄し，X-GlcA を $500 \mu \mathrm{g} \mathrm{mL}^{-1}$ の濃度で添加した緩衝液に浸せきした後, $37^{\circ} \mathrm{C} て ゙ 12 〜 24$ 時間インキュベートすればよい(第 2 図 A,B).

なお，GUS や LakZ の発色は植物組織でも同種の酵素で 発現することがある. その場合は, 予めメ夕ノールや脱色 剤で植物側の遺伝子発現（バックグラウンド）を消去して おく，一方, GFP は蛍光顕微鏡の下で生体観察できるので, 植物組織の自家蛍光との差が明確であれば菌の挙動を生体 で経時的に観察できる。なお, 根粒菌への標識遺伝子の導 入は, 組換え DNA 実験計画を申請して行わなければなら ないことは言うまでもない.

発色標識遺伝子を活用することで菌の感染様式について 多くの情報が得られた。著者らも緑肥作物であるCrotalaria juncea の感染様式を調べるために gus $A$ 遺伝子導入菌株を 使って感染糸の形成を確認した（第 2 図 C)。一般には, 子実用や飼料用のマメ類は, 感染糸経由のグループに属し, 細胞間隙から侵入するグループにはラッカセイやSesbania rostrata などがあげられる，S. rostrataでは，土壤水分条件 によって感染様式に可塑性がみられるなどの興味深い報告 もなされている (Goormachtig ら 2004)。ここで概略した 観察手法は, 変動する土壌環境における根粒菌の挙動とマ メ科作物の根粒形成についての理解を深める一助となるで あろう。

\section{引用文献}

Akao, S., Y. Minakawa, H. Taki, M.K. Khan, K. Yuhashi, Y. Nakayama, C.A. Asis Jr., V.Chebotar, U. Kang, K. Minamisawa and R.W. Ridge 1999. Use of $l a c Z$ and $g u s A$ reporter genes to trace the infection process of nitrogen-fixing bacteria. JARQ. $33:$ 77-84.

Dilworth, M.J. 1980. Leghemoglobins. In: A.S. Pietro(ed.), Methods in Enzymology 69, pp. 812-823. Academic Press, New York.

Goormachtig, S., W. Capoen, and M. Holsters 2004. Rhizobium infection: lessons from the versatile nodulation behaviour of water-tolerant legumes. Trends Plant Sci. 9 : 518-522.

皆川律子・磯田香保理 - 大竹憲邦 - 山田真也 - 五十嵐太郎 - 南沢究 大山卓爾 1997. GUS 代謝産物のフェノール抽出による土袞中の 
gus 導入根粒菌数の推定. 土肥誌 $68: 148-155$.

Niwa, S., M. Kawaguchi, H. Imaizumi-Anraku, S.A. Chechetka, M. Ishizaka, A. Ikuta, H. Kouchi 2001. Responses of a model legume Lotus japonicus to lipochitin oligosaccharide nodulation factors purified from Mesorhizobium loti JRL501. MPMI. 14 : 848-856.

Uheda, E., H. Daimon, and F. Yoshizako 2001. Colonization and invasion of peanut (Arachis hypogaea L.) roots by gusA-marked Bradyrhizobium sp.. Can. J. Bot. $79: 733-738$.

Wilson, K.J. 1995. Molecular techniques for the study of rhizobial ecology in the field. Soil Biol. Biochem. $27: 501-514$.

Yuhashi, K., K. Minamisawa, Y. Minakawa, D.J. Tobias, M. Kubota and S. Akao 1997. Nodulation and competitiveness of $g u s A$-marked Bradyrhizobium japonicum A1017 in soybean. Soil Sci. Plant Nutr. $43: 473-478$.

\section{書 評}

「環境保全型農業事典」石井龍一 編, 丸善株式会社, 東京, 2005 年, 902 頁, 20,000 円.

作物がもつ潜在的生産ポテンシャルを十分に発揮させ，高収量，高品質を達成することが作物学研究の目的の一つ であることは言うまでもない。一方，このような展開の方向は，農耕地生態系の保全や生産の持続性といった視点に 欠けることがあり，生産性向上のために環境インパクトを大きくしてしまう場合がある。地球環境の劣德化と耕作可 能面積の減少が叫ばれる中，限られた資源の有効な利用や農耕地のもつ物質循環機能に着目した生産技術の開発と展 開は急務であり，多くの研究者，技術者，そして生産者の目的とするところとなっている.

編者が序文に引用した Evans 博士の「世界の人口，耕地ならびに作物の収量と窒素使用量」に関するデー夕をこの 分野に携わる多くの者は目にしたことがあるであろう。このデータの 2005 年以降のシナリオはどのようになっている のであろうか。望ましくないシナリオであれば修正しなければならない. 本書はこのシナリオを書き直すべき研究者, 技術者，生産者そして消費者の必読の書である。環境保全に立脚した持続的な農業を実行するために知っておかなけ ればならない作物の特性, 施肥管理技術, 病害虫防除技術, 作付体系の特徴などがとてもわかりやすく解説されている. 先ず, 総論編として稲栽培, 畑作物栽培, 野菜栽培, 果樹栽培などの現状とそれらが環境に与える影響について概説 されている。ささらに，各論編として，土壤，肥料，作付体系，圃場管理，雑草，病害虫，バイオマス資源，バイオテ クノロジー，多面的機能，地球環境変化，畜産の各章において，環境保全の視点から農業生産を見直すための基盤と なる多くの情報が，130人に上る第一線の研究者によってまとめ上げられている．本書は事典という名ではあるが，総 論編からじっくりと読むことによって，環境保全型農業を理解するための教科書としても利用できる。もちろん，多 くの写真と理解しやすい図に加えて，わかりやすく分類された各項目は，文字通り「事典」として利用する面でもひ じょうに便利である，私も本書を通読した後に，早速，いくつかの用語をひいて知識を更新した。

(大阪府立大学大学院 大門弘幸) 